\title{
Conceptual Design of Motion Reduction Device for Floating Wave-Offshore Wind Hybrid Power Generation Platform
}

\author{
Sewan Park*, Kyong-Hwan Kim and Keyyong Hong@* \\ "Korea Research Institute of Ships \& Ocean Engineering, KRISO, Daejeon, Korea \\ 부유식 파력-해상풍력 복합발전 플랫폼의 운동저감장치 개념설계 \\ 박세완 · 김경환 $^{*}$ 홍기용요 \\ "선박해양플랜트연구소 해양에너지연구부
}

KEY WORDS: Wave-offshore wind hybrid power generation 파력-해상풍력 복합발전, Motion reduction device 운동저감장치, Damping plate 감쇠판, Boundary element method 경계요소법, 2D wave flume model test 2차원 조파수조 모형실험

\begin{abstract}
The present study deals with the conceptual design of a motion reduction device for a floating wave-offshore wind hybrid power generation platform. A damping plate attached to the bottom of a column of a large semi-submersible is introduced to reduce the motion of the platform. Performance analyses on various shapes and configurations of damping plates were performed using the potential flow solver, and the appropriate configuration and size of the damping plate were selected based on the numerical results. In order to see the effect of viscous damping, a small scale model test was performed in a $2 \mathrm{D}$ wave flume. The performances of five different damping plates were measured and discussed based on the results of free decay tests and regular wave tests.
\end{abstract}

\section{1. 서 론}

파력, 조류, 조력, 해수온도차 등의 해양에너지원은 화석연료 를 대체하는 신재생에너지로서 인류의 미래 에너지원으로 각광 받고 있다. 오늘날 전세계 25 개가 넘는 국가에서 해양에너지원 을 활용한 에너지 생산 기술 개발에 매진하고 있으며, 해양에너 지원 중 파력에너지를 활용하는 파력발전 분야는 다수의 실해 역 실증이 이루어져 상용화에 근접해 있는 분야 중 하나이다 (NRG Expert, 2011; Enferad and Nazarpour, 2013). 신재생에너지 원 중 가장 먼저 상용화를 이루었던 풍력발전은 육상 및 근해 에서의 개발 제한으로 인해 점차 심해 부유식 영역으로 확장되 고 있다(Butterfield et al., 2005). 그러나 해양에너지를 이용한 발 전은 화석연료를 이용한 발전에 비하여 경제성이 낮다는 단점 이 있으며, 이는 해양에너지 발전시스템의 상용화를 지연시키 는 원인이 되고 있다. 최근 해양에너지 발전시스템의 경제성 향 상을 위하여 다수의 해양에너지원을 복합적으로 발전하는 시스 템을 개발하려는 시도가 이루어지고 있으며, 계류계, 전력변환, 계통연계, 이송/설치 등의 비용을 절약할 수 있는 시스템에 대
한 연구가 이루어지고 있다. 특히 환경 적지가 일치하는 파력과 풍력을 동시에 발전하는 발전시스템의 개발 및 실해역 시험이 유럽을 중심으로 수행되고 있으며, MARINA platform project (Soulard et al., 2013), H2Ocean project(Palomar, 2013), P80(Yde et al., 2015) 등이 대표적이다. 국내에서도 선박해양플랜트연구소 (KRISO, Korea Research Institute of Ships and Ocean Engineering) 주관으로 2013년부터 2016년까지 부유식 파력-해상풍력 연계형 발전시스템 설계기술 개발에 대한 연구가 수행되었으며, 부유 식 플랫폼에 다수의 풍력터빈 및 파력발전기를 탑재하고 통합 전력제어시스템을 통해 복합 해양에너지원을 동시에 활용하고 자 하는 발전시스템에 대한 개념설계가 완료되었다(Kim et al., 2015).

부유식 파력-해상풍력 연계형 발전시스템 설계기술 개발 연 구과제에서 개발된 발전시스템은 반잠수식 플랫폼 형태이며, 플랫폼의 네 모서리에 위치한 컬럼(Column) 상부에는 로터 직 경 $105 \mathrm{~m}$ 에 달하는 풍력터빈 4 기가 각각 배치되어 있다. 본 구 조물은 수평면상 전후좌우 대칭인 구조이고 길이와 폭이 각각 $150 \mathrm{~m}$ 에 달하는 대형 구조물이다. 트러스(Truss) 구조로 고안되

Received 8 March 2017, revised 11 January 2018, accepted 1 February 2018

Corresponding author Keyyong Hong: +82-42-866-3912, khong@kriso.re.kr ORCID: https://orcid.org/0000-0002-7284-3248 It is noted that this paper is revised edition based on proceedings of ISOPE 2015 in Kona. 


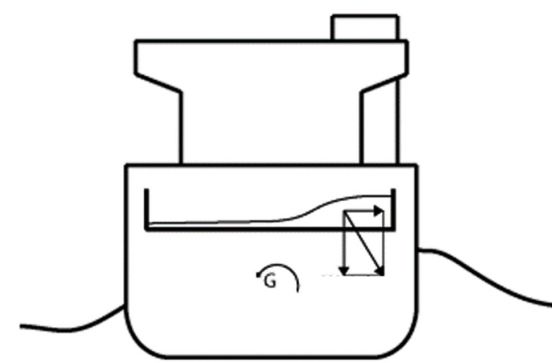

(a) Tuned liquid damper (Iglesias et al., 2004)

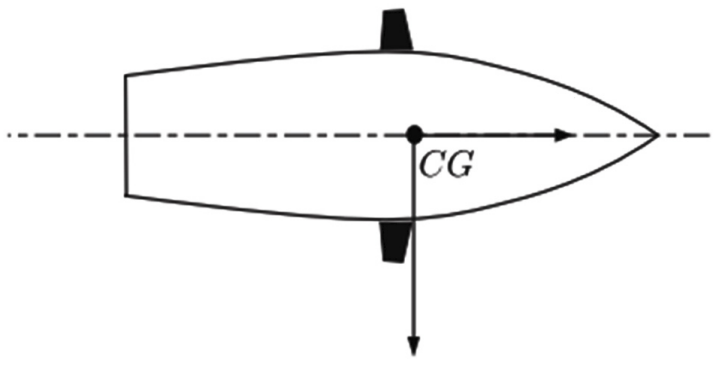

(c) Fin stabilizer (Perez and Goodwin, 2008)

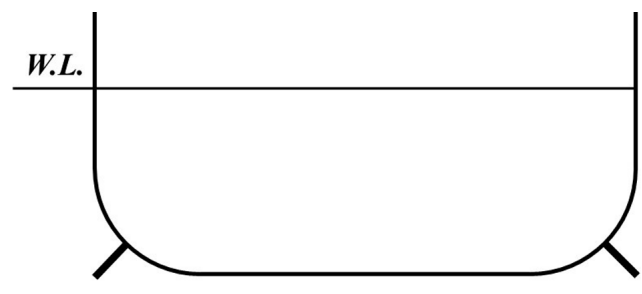

(b) Bilge keel (Katayama et al., 2010)

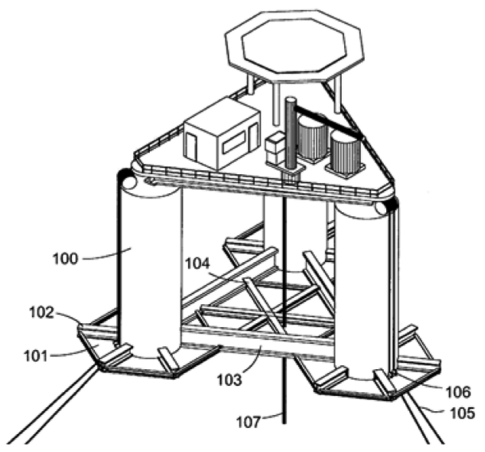

(d) Damping plate (Busso, 2006)

Fig. 1 Type of motion reduction device used in the ship and offshore structure

었기 때문에 통상적인 반잠수식 구조물에 비해 컬럼, 폰툰 (Pontoon) 등의 주요부재의 종횡비(Aspect ratio)가 크다는 특징 이 있다. 초기에 설계된 구조물의 상하동요, 횡동요, 종동요 등 의 고유주기는 약 14 초이고, 통상적인 반잠수식 구조물에 비해 공진주기가 파랑주파수에 근접하여 공진 운동의 위험성이 있었 다(Park et al., 2014). 한편 풍력터빈 나셀(Nacelle)은 다수 풍력 터빈 배치의 특성상 플랫폼 무게중심으로부터 먼거리에 위치하 게 되며, 플랫폼의 작은 횡동요 및 종동요에도 큰 회전가속도를 경험하게 된다. 결과적으로 플랫폼의 과도한 운동은 나셀과 로 터의 구조 안전성 및 운용성에 악영향을 미칠 수 있기 때문에 적절한 운동 저감 장치가 필요하다.

선박 및 해양구조물의 과도한 운동을 억제하기 위한 장치들 은 동조액체감쇠장치(Tuned liquid damper), 빌지킬(Bilge keel), 핀 안정기(Fin stabilizer), 수평판(Horizontal plate) 또는 감쇠판 (Damping plate), 트러스 폰툰(Truss-pontoon) 등 다양한 형태가 존재한다(Fig. 1). 최근 부유식 풍력터빈에 대해 비용 대비 효과 가 높은 감쇠판 형태가 주로 채택되고 있다. Cermelli et al. (2004)은 반잠수식 해양구조물 하단에 감쇠판을 부착한 모델에 대해 주파수 영역 포텐셜 수치해석을 수행하여 공진주기 이동 및 운동저감 효과를 보였으며, Cermelli and Roddier(2005)은 모 형실험 및 시간영역 수치해석 결과를 비교하고 불규칙파 조건 에서의 운동응답 결과를 검토하였다. 이는 Water entrapment plate(Busso, 2006)로 특허화되었고 부유식 해상풍력발전기인 WindFloat에 적용되었다(Cermelli et al., 2009). 이외에도 스파 (Spar) 구조물에 부착된 감쇠판에 대한 운동저감효과가 수치적 및 실험적으로 검토되었으며(Koh and Cho, 2016; Rho and Choi, 2002; Pauline and Adrien, 2015; Javier et al., 2015; Subbulakshmi and Sundaravadivelu, 2015), Tao and Cai(2004)의 연구에서는 $\mathrm{CFD}$ (Computational fluid dynamics) 해석을 통해 감쇠판의 크기
및 두께 등에 대해 와류 발생에 기인한 점성감쇠 영향을 검토 한 바 있다.

부유식 파력-해상풍력 연계형 발전시스템 설계기술 개발 연 구과제에서도 플랫폼의 공진회피 및 과도한 회전운동 저감을 위한 운동저감장치 개발이 요구됨에 따라 문헌조사와 수치해석 및 모형실험에 기반한 운동저감장치 설계가 수행되었다. 본 연 구에서는 운동저감장치의 다양한 부착형태 및 크기에 대한 수 치해석 결과와 도출된 설계안을 소개한다. 또한 점성감쇠 효과 를 증진시킬 목적으로 고안된 감쇠판 형태들을 소개하고 2차원 조파수조 모형실험을 통한 운동응답 계측 결과들을 비교하여 제시한다. 이로부터 대형 반잠수식 플랫폼의 운동저감을 위한 감쇠판의 형태에 대해 논의한다. 본 논문은 대상 구조물인 복합 발전 플랫폼 및 운동저감장치의 형상 정의, 적용한 수치해석 기 법 및 모형실험 방법 소개, 수치해석 및 모형실험 결과, 결론 순 으로 서술되었다.

\section{2. 해석 대상}

\section{1 대상 플랫폼}

복합발전 플랫폼의 주요 치수를 Table 1 에 나타내었다. 풍력발 전기 4기 및 파력발전기 24기를 플랫폼에 탑재하는 대형 반잠수 식 구조물이다. 플랫폼의 수면하부 선체는 컬럼(Column), 내/외 부폰툰(Outer/inner pontoon), 폰툰대각보강재(Pontoon diagonal brace), 수직보강재(Vertical brace), 파력발전기부이(Wave energy converter buoy), 파력발전기지지구조로 구성되어 있다. 수치해석 모델에서는 선체 배수량 기여도가 낮은 파력발전기 지지구조를 배제하였다. Fig. 2에는 복합발전 플랫폼의 형상을 나타내었다. 세장체적 특성을 지닌 복합발전 플랫폼의 구조요소들은 $\mathrm{DNV}$ (Det Norske Veritas)에서 권장하고 있는 해양구조물의 환경하중 
Conceptual Design of Motion Reduction Device for Floating Wave-Offshore Wind Hybrid Power Generation Platform 11

Table 1 Principal dimensions of the baseline platform

\begin{tabular}{cc}
\hline \hline Items & Value \\
\hline LOA $[\mathrm{m}]$ & 158.5 \\
Height $[\mathrm{m}]$ & 27 \\
Draft $[\mathrm{m}]$ & 15 \\
Total weight [MT] & 23,285 \\
\hline
\end{tabular}

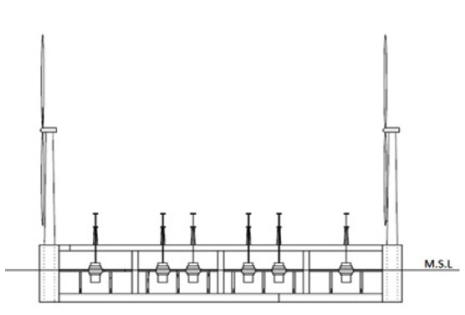

(a) Elevation view

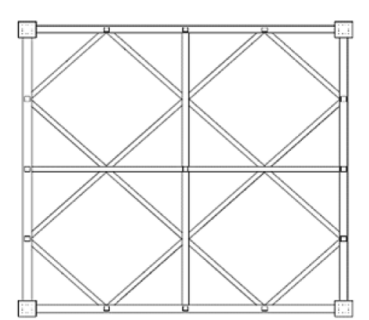

(b) Plan view
Fig. 2 Baseline platform geometry

Table 2 Categorization of the dominant wave force for the structure component

\begin{tabular}{ccc}
\hline \hline Items & Regime & Category \\
\hline Column & Large inertia & Primary structure \\
Outer/inner pontoon & Large inertia & \\
\hline Pontoon diagonal brace & Inertia and drag & Secondary structure \\
Vertical brace & Inertia and drag & \\
WEC buoy & Inertia and drag & \\
\hline
\end{tabular}

모델링 가이드라인(DNV, 2010)에 따라 수치해석 모델로 모델링 되었다. $\mathrm{DNV}$ 가이드라인에서는 해양구조물과 파랑의 상대적
크기에 따른 지배적인 하중을 제시하고 있는데, Table 2와 같이 복합발전 플랫폼의 수면하부 구조 요소에 대해 상대적 크기 별 로 지배적인 하중 영역을 구분하여 주요부재(Primary structure) 및 보조부재(Secondary strcuture)로 분류하였다.

\section{2 운동저감장치}

감쇠판 형태의 운동저감장치는 플랫폼 부가질량, 점성감쇠를 증가시키면서도 파랑기진력도 증가시키기 때문에 운동저감의 관점에서 해당 효과들은 서로 상충되며(Cermelli et al., 2004), 운 동응답은 감쇠판의 부착형태 및 크기에 따라 달라질 수 있다. 따라서 본 연구에서는 감쇠판의 다양한 배치형태와 크기를 개 념설계의 설계인자로 정의하였다.

\subsection{1 감쇠판의 배치형태}

감쇠판의 배치형태에 따른 운동저감 성능을 판별하기 위하여 우선 감쇠판의 크기를 고정하였다. Park et al.(2014)의 연구에서 는 WindFloat의 컬럼과 감쇠판 크기 비율을 고려하여 복합발전 구조물의 운동저감장치를 제안한 바가 있으며, 본 연구에서는 Park et al.(2014)에서 제시한 감쇠판의 크기를 적용하였다. 민감 도 해석을 위하여 제안된 감쇠판의 배치형태를 Fig. 3에 나타내 었다. 그림은 수평면상에서 전후좌우로 대칭인 복합발전 플랫 폼의 $1 / 4$ 형상만을 평면도로 나타낸 것이며, 주요부재인 컬럼, 내/외부폰툰, 감쇠판만 나타내었다. 그림에서 $A_{p}$ 는 컬럼 단면적 대비 감쇠판의 단면적 비율을 의미하며, Base model은 운동저감 장치가 부착되지 않은 알몸 선체(Bare hull) 모델, Pre model은 Park et al.(2014)에 제시된 감쇠판, Num. model A D는 새롭게 고안된 운동저감장치 설계 모델이다. Base model에 나타낸 컬럼 의 단면은 가로 및 세로길이가 $8.5 \mathrm{~m}$ 인 정사각형이며, 절반만 나 타낸 외부폰툰은 길이가 $70.75 \mathrm{~m}$, 단면의 가로 및 세로 길이는 모두 $4 \mathrm{~m}$ 이다.

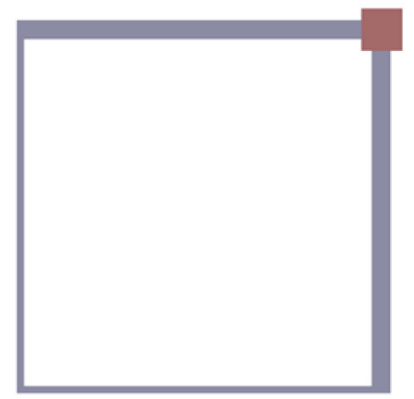

(a) Base model, $A_{p}=1.0$

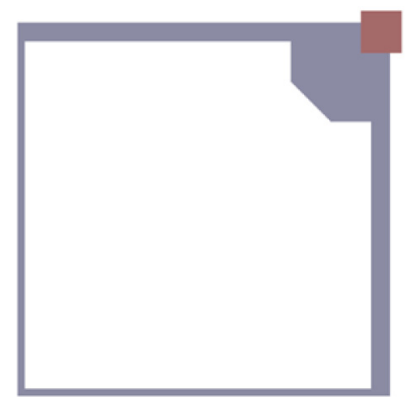

(d) Num. model B, $A_{p}=3.2$

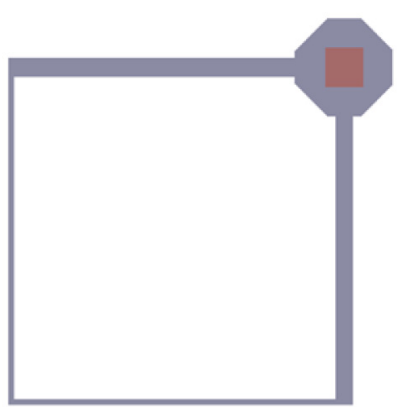

(b) Pre model, $A_{p}=3.2$

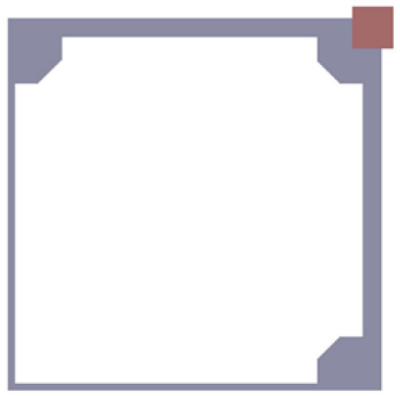

(e) Num. model C, $A_{p}=3.2$

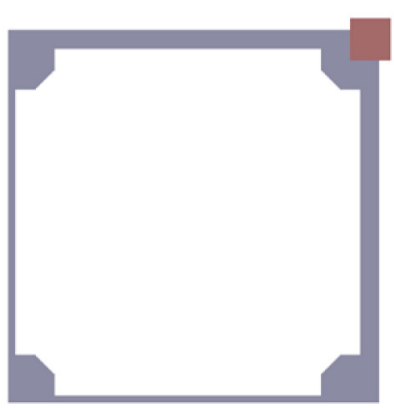

(c) Num. model A, $A_{p}=3.2$

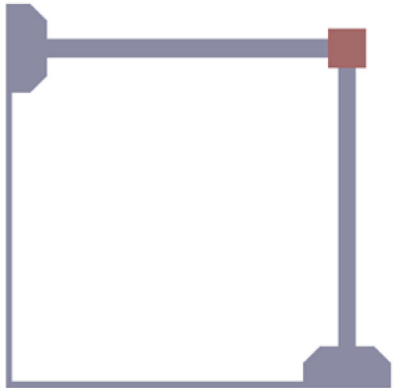

(f) Num. model D, $A_{p}=3.2$

Fig. 3 Various configurations of the horizontal plate for the motion reduction device 


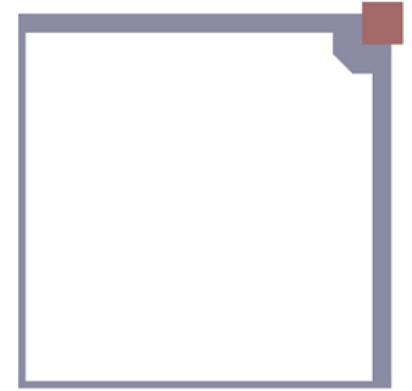

(a) Num. model $\mathrm{B}_{-2}, A_{p}=0.8$

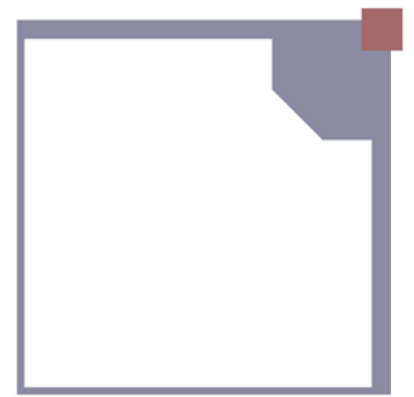

(d) Num. model $\mathrm{B}_{+1}, A_{p}=5.1$

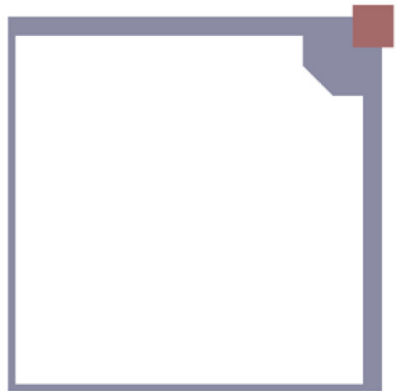

(b) Num. model $\mathrm{B}_{-1}, A_{p}=1.8$

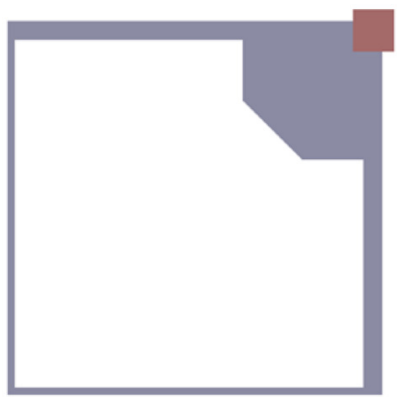

(e) Num. model $\mathrm{B}_{+2}, A_{p}=7.4$

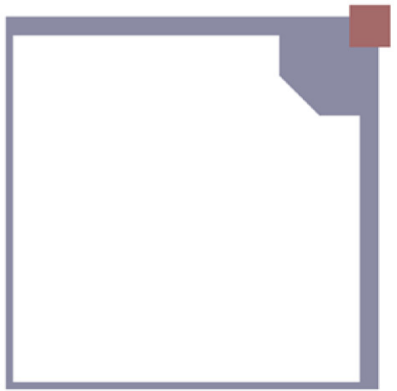

(c) Num. model B, $A_{p}=3.2$

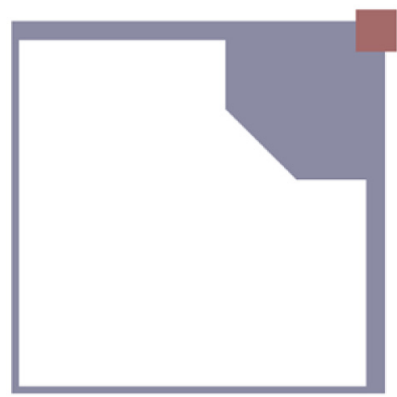

(f) Num. model $\mathrm{B}_{+3}, A_{p}=10.1$

Fig. 4 Various sizes of the horizontal plate for the motion reduction device

\subsection{2 감쇠판의 크기}

감쇠판의 다양한 배치형태에 대해, 수치해석을 통해 가장 좋 은 운동성능을 보이는 배치형태를 선정하고, 해당 배치형태를 기준으로 감쇠판의 크기를 변화시키며 성능을 평가하였다. Fig. 4에는 최적 배치형태로 선정된(Fig. 10) Num. model B를 바탕으 로 감쇠판의 크기를 변화시켜 민감도 해석을 수행한 모델들을 나타내었다. 선정된 모델의 감쇠판과 컬럼의 상대면적비는 3.2 이며(Fig. 4(c)), 이를 기준으로 0.8 10.1 범위의 상대면적을 고려 하였다.

\section{3. 운동저감장치 민감도 해석 방법}

운동저감장치의 감쇠판 배치형태 및 크기에 대한 민감도 수 치해석은 DNV-GL의 Wadam을 이용하여 수행하였다. Wadam은 포텐셜 유동 이론 기반의 경계치 문제를 파랑그린함수를 적용 하여 주파수 영역에서 해석하는 프로그램으로, 선박 및 해양구 조물의 운동성능 해석에 활용되고 있는 상용 프로그램이다.

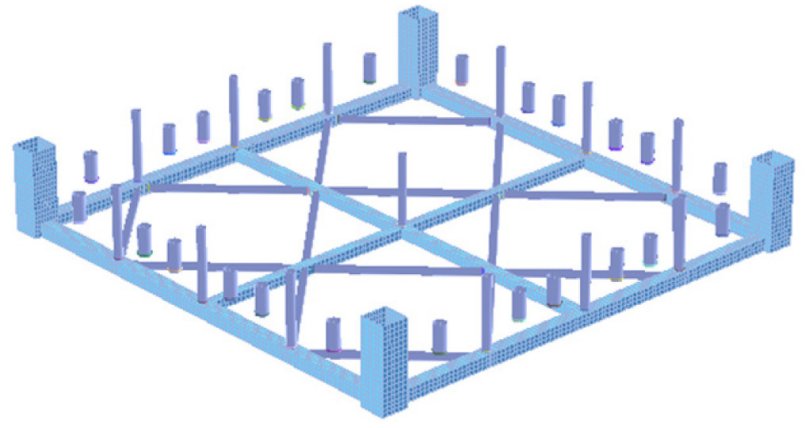

(a) Base model
Table 2에서 주요부재로 분류된 구조 요소 및 감쇠판에 대해서 는 패널(Panel)로 모델링하여 경계요소법을 통한 산란 및 방사 문제를 해석하고, 보조부재로 분류된 구조 요소는 모리슨 보 (Morison beam)로 모델링하여 모리슨 식(Morison's equation)을 통해 보조부재에 작용하는 관성력 및 점성항력을 계산하여 플 랫폼의 운동방정식에 적용하였다. 최종적으로 수립된 플랫폼 운동방정식은 식 (1)과 같다.

$$
\left[-\omega^{2}(\boldsymbol{M}+\boldsymbol{A}(\omega))+i \omega\left(\boldsymbol{B}_{p}(\omega)+\boldsymbol{B}_{a}+\boldsymbol{B}_{v}\right)+\boldsymbol{C}\right] \boldsymbol{X}(\omega, \beta)=\boldsymbol{F}(\omega, \beta)
$$

이때, $\boldsymbol{M}$ 은 플랫폼 질량 행렬, $\boldsymbol{A}$ 는 부가질량 행렬, $\boldsymbol{B}_{p}$ 는 파랑감 쇠 행렬, $\boldsymbol{B}_{\boldsymbol{a}}$ 는 부가감쇠 행렬, $\boldsymbol{B}_{v}$ 는 선형화된 점성감쇠 행렬, $\boldsymbol{C}$ 는 복원력 행렬, $\boldsymbol{X}$ 는 운동 변위 벡터, $\boldsymbol{F}$ 는 파랑 기진력 및 모 리슨 외력 벡터, $\omega$ 는 파랑 주파수, $\beta$ 는 입사파 입사각을 나타 낸다.

산란 및 방사문제 해석에 대한 상세 이론은 WAMIT theory manual에 수록되어 있으며(Lee, 1995), 모리슨 방정식의 적용은

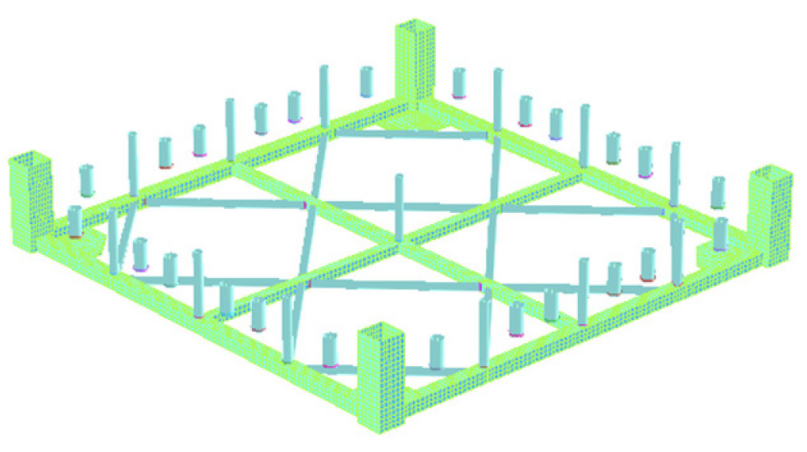

(b) Num. model B

Fig. 5 Numerical analysis models for the Base Model and the Num. model B 
Wadam user manaul에 기술되어 있다(DNV, 2013). 패널 모델은 DNV-GL Sesam Genie를 통해 생성하였으며, 패널의 단위 요소 크기는 모든 모델에 대해 $1.6 \mathrm{~m}$ 로 적용하였으며, 이는 공진주파 수 파장에 대해 약 $0.4 \%$, 최장주기파 파장에 대해 약 $0.1 \%$ 수준 에 해당된다. Fig. 5 에는 복합발전 플랫폼의 Base model 및 Num. model B의 유체동역학 해석 모델을 나타내었다. 각각 $1 / 4$ 모델 에 대해 2,236 개 및 2,428 개의 패널이 분포되었으며, 보조부재의 모리슨 보요소 모델이 함께 반영되었다.

실제로는 주요 부재로 인하여 발생되는 점성감쇠가 있을 수 있으며 본 연구에서는 플랫폼 주요부재 모델에 대한 임계감쇠 값의 $5 \%$ 를 모든 해석 모델에 대해 동일하게 부가감쇠로 부여하 였다. 해당 임계감쇠 값은 플랫폼 주요부재에 모리슨 방정식의 항력을 부여한 수치해석 모델의 운동응답 계산 결과와의 비교 로부터 산출되어 적용되었다.

감쇠판은 크게 부가질량의 증가, 파랑기진력의 증가, 점성감 쇠의 증가에 영향을 미친다. 본 연구에서는 1 차적으로 포텐셜 유동 해석을 통하여 부가질량의 증가 및 기진력의 증가를 고려 하고 파랑주파수의 공진을 회피하는 설계를 채택하였다. 그리 고 선정된 안을 바탕으로 2차원 수조모형실험을 수행하여 점성 감쇠의 영향을 정성적으로 살펴보았다. 따라서 수치해석에서는 감쇠판을 패널로 모델링하여 적용하였다.

\section{4. 운동저감장치 감쇠효과 평가 모형실험}

감쇠판의 점성감쇠는 감쇠판의 끝단에서 유기되는 와류와 관 계가 있으며(Tao and Cai, 2004), 와류가 많이 발생할수록 플랫 폼에 작용하는 점성감쇠가 증가하여 플랫폼의 운동 응답을 감 쇠시키게 된다. 본 연구에서는 감쇠판의 배치형태 및 크기에 대 한 수치해석 결과로부터 도출한 1차 설계안을 기반으로하여, 점 성감쇠의 효과를 증진시키기 위해 감쇠판의 개수를 변화시키거 나 공극을 반영하는 등의 형태를 추가적으로 고려하였으며, 이 의 점성감쇠를 고려한 운동저감 성능을 정성적으로 평가하기 위해 2차원 조파수조 모형실험을 수행하였다.

본 모형실험에서는 다양한 감쇠판 모델들의 점성감쇠 영향을 주로 종동요 운동저감 관점에서 살펴보는 것이 목적이므로, 복 합발전 플랫폼에 대해 전체 형상을 정확하게 모델링하는 것 보 다는 2차원 조파수조의 크기, 계류방법, 모형 제작성 등을 고려 하여 실험 수행이 가능하도록 모델링하는 것이 유의미하다고 판 단하였다. 즉, 복합발전 플랫폼 전체 형태 중 컬럼-외부폰툰-컬럼 연결부만을 실험 모형으로 고려하고, 각 부재의 단면은 $1 / 70$ 크 기로 축소시켰으며, 그 중 외부폰툰의 전체 길이는 $1 / 2$ 로 절단시 켜 이상화하였다. 각 감쇠판은 컬럼 외측 하단에 부착하였으며, 이상화 된 모델의 종동요 공진주파수, 조파기 성능범위를 고려 하여 파주파수 3 5.5rad/s 범위의 규칙파를 모델에 입사시켰다. 수치해석에서 고려된 3차원 형상과 모형실험에서 고려된 2차원 형상간의 상사성이 유지되지 않으나, 수치해석으로부터 도출한 개념설계안의 점성감쇠가 고려된 성능을 주어진 실험환경에서 정성적으로 평가하기 위하여 상기와 같은 전략을 채택하였다.

Table 3에는 모형실험을 수행한 선박해양플랜트연구소의 2차 원 조파수조 제원을 나타내었고, Table 4 에는 감쇠판이 부착되
Table 3 Specifications of the 2D wave flume in KRISO

\begin{tabular}{cc}
\hline \hline Items & Value \\
\hline Length $[\mathrm{m}]$ & 30 \\
Width $[\mathrm{m}]$ & 0.6 \\
Height $[\mathrm{m}]$ & 1 \\
Water depth $[\mathrm{m}]$ & 0.5 \\
Maximum wave height $[\mathrm{m}]$ & 0.15 \\
Wave period range $[\mathrm{s}]$ & $0.75 \sim 2.4$ \\
\hline
\end{tabular}

Table 4 Specifications of the barehull model for the 2D wave flume experiment

\begin{tabular}{cc}
\hline \hline Items & Value \\
\hline Column section $[\mathrm{cm} \times \mathrm{cm}]$ & $13.0 \times 13.0$ \\
Column height $[\mathrm{cm}]$ & 38.6 \\
Pontoon section $[\mathrm{cm} \times \mathrm{cm}]$ & $6.0 \times 6.0$ \\
Pontoon length $[\mathrm{cm}]$ & 101.1 \\
Draft $[\mathrm{cm}]$ & 26.4 \\
\hline
\end{tabular}

지 않은 모델의 모형 제원을 나타내었다.

Fig. 6에는 모형실험에 적용된 실험모델의 형상을 나타내었 다. Exp. model A는 알몸선체 모델, Exp. model B는 단일 감쇠 판이 부착된 모델, Exp. model $\mathrm{C}$ 는 단일 감쇠판 중앙에 공극이 있는 모델, Exp. model D는 박스형 감쇠구조물이 부착된 모델, Exp. model E는 Exp. model B에 적용된 감쇠판을 간격을 두어 이중으로 부착한 모델, Exp. model $\mathrm{F}$ 는 Exp. model $\mathrm{C}$ 에 적용된 감쇠판을 간격을 두어 이중으로 부착한 모델이며, 단일 감쇠판 의 공극을 제외한 총 수평면적은 모든 모델에 대해 동일하다. Exp. model B의 경우 컬럼 단면과 동일한 치수의 감쇠판이 적 용되었으며, Exp. model C의 공극에 대해서는 길이 $8.7 \mathrm{~cm}$ 및 폭 $6.5 \mathrm{~cm}$ 가 적용되었다. Exp. model $\mathrm{D}$ 의 박스형 감쇠구조물의 높 이는 폰툰 높이와 동일한 $6 \mathrm{~cm}$ 이며, Exp. model E 및 $\mathrm{F}$ 의 감쇠판 사이의 간격도 $6 \mathrm{~cm}$ 로 적용되었다. Exp. model $\mathrm{B}, \mathrm{C}, \mathrm{E}, \mathrm{F}$ 에 적 용된 각 감쇠판의 두께는 모두 $0.6 \mathrm{~cm}$ 이다. 알루미늄 및 엔지니 어링 플라스틱을 이용하여 제작된 모델을 한 쪽 컬럼부분만 확 대 촬영하여 Fig. 7에 나타내었으며, Table 5에는 각 모델의 무 게 정보를 나타내었다. 본 모형실험에서는 서로 다른 감쇠판을 부착할 때마다 각 모형들이 같은 무게, 흘수, 관성 반경등을 갖 도록 제작하는 것이 용이하지 않았는데, 이는 감쇠판의 형태에 따라 배수량과 무게가 동시에 변화하며 모형 자체가 작아 변화 하는 배수량에 대응할 수 있는 추가적인 추 배치에 한계가 있 었기 때문이다. 본 연구에서는 감쇠판이 바뀌어도 동일한 흘수 에서 모형실험이 수행되도록 감쇠판마다 컬럼 하부에 배치한 추의 무게를 조정하여 흘수를 맞추고 실험하였다. Table 5에 나 타낸 무게중심과 관성반경은 경사실험 및 그네실험으로 추산한 결과이다.

모델은 2 차원 수조 내에 길이 약 $76 \mathrm{~cm}$, 강성 $0.1 \mathrm{~kg} / \mathrm{m}$ 의 스프 링으로 4점 계류하여 설치하였으며, 모델의 운동은 VICON사의 T40-Camera를 활용한 Motion capture system을 통해 계측하였다. 


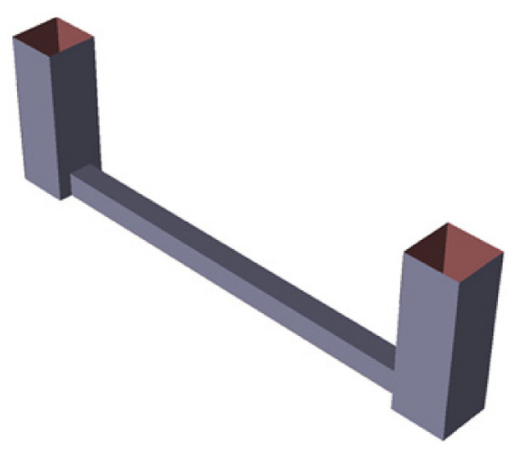

(a) Exp. model A

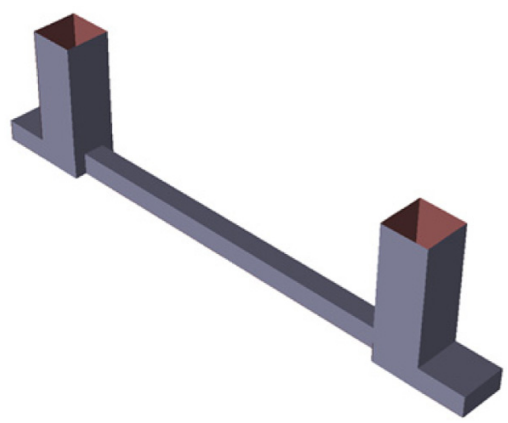

(d) Exp. model D

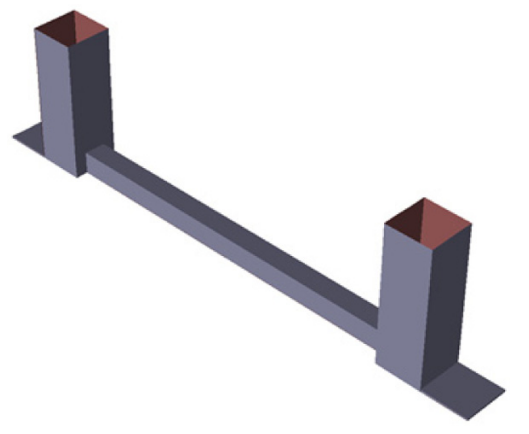

(b) Exp. model B

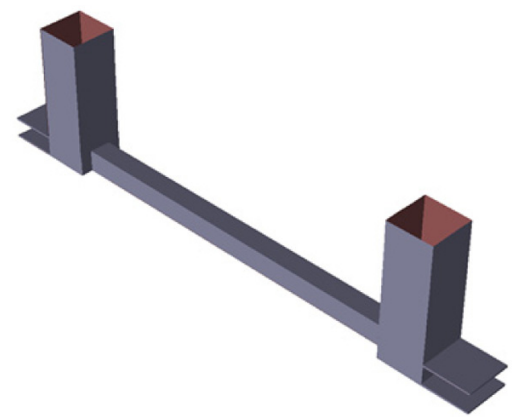

(e) Exp. model E

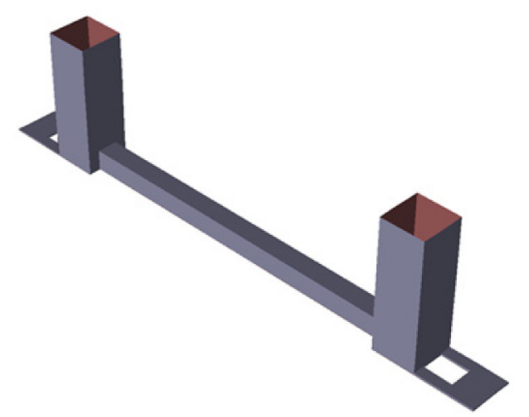

(c) Exp. model C

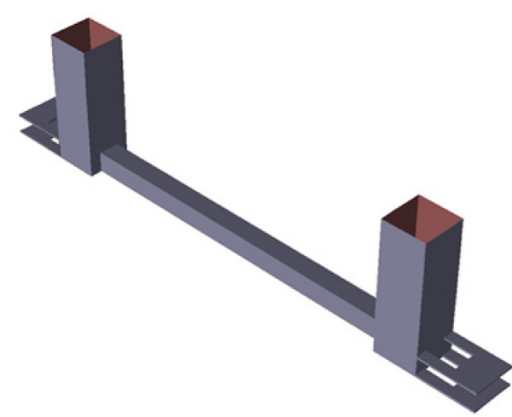

(f) Exp. model F

Fig. 6 Simplified platform models for 2D wave flume experiment

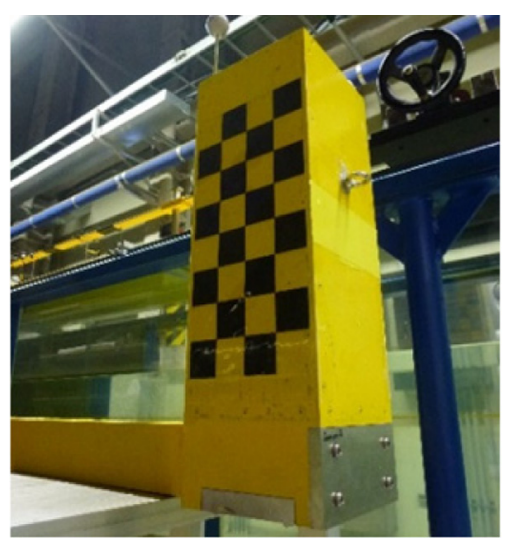

(a) Exp. model A

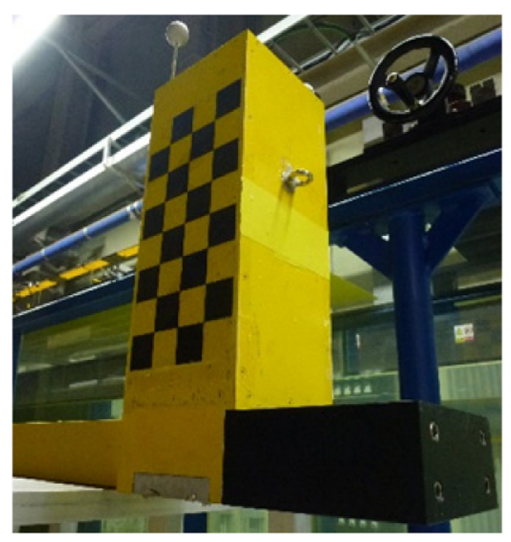

(d) Exp. model D

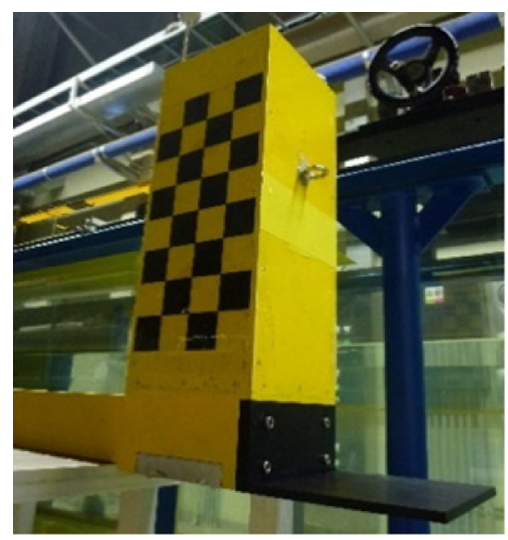

(b) Exp. model B

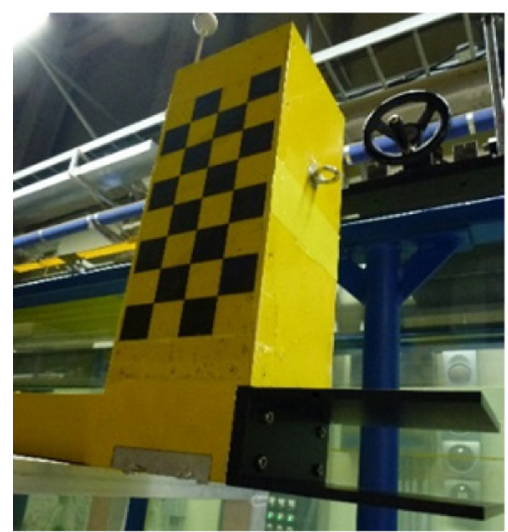

(e) Exp. model E

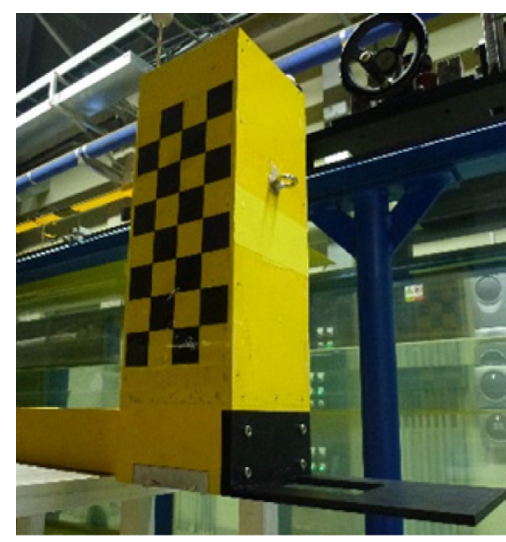

(c) Exp. model C

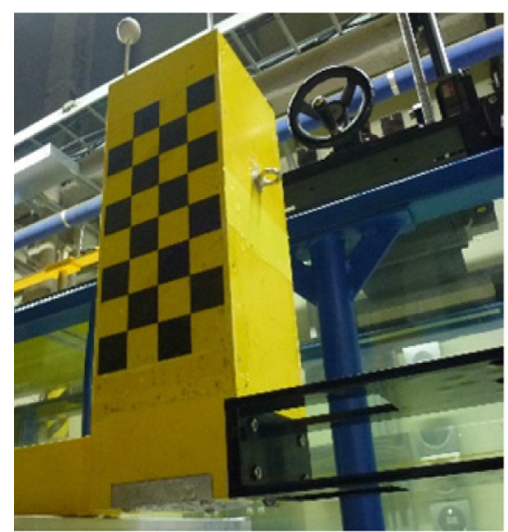

(f) Exp. model F

Fig. 7 Manufactured platform models for 2D wave flume experiment 
Conceptual Design of Motion Reduction Device for Floating Wave-Offshore Wind Hybrid Power Generation Platform 15

Table 5 Weight information of manufactured platform models

\begin{tabular}{cccc}
\hline \hline Items & Displacement $[\mathrm{kg}]$ & Center of gravity above keel [cm] & Pitch radius of gyration [cm] \\
\hline Exp. model A & 12.3 & 7.3 & 58.0 \\
Exp. model B & 12.6 & 7.4 & 75.3 \\
Exp. model C & 12.6 & 7.5 & 78.6 \\
Exp. model D & 14.4 & 7.0 & 74.0 \\
Exp. model E & 12.6 & 7.2 & 71.8 \\
Exp. model F & 12.6 & 7.2 & 75.4 \\
\hline
\end{tabular}

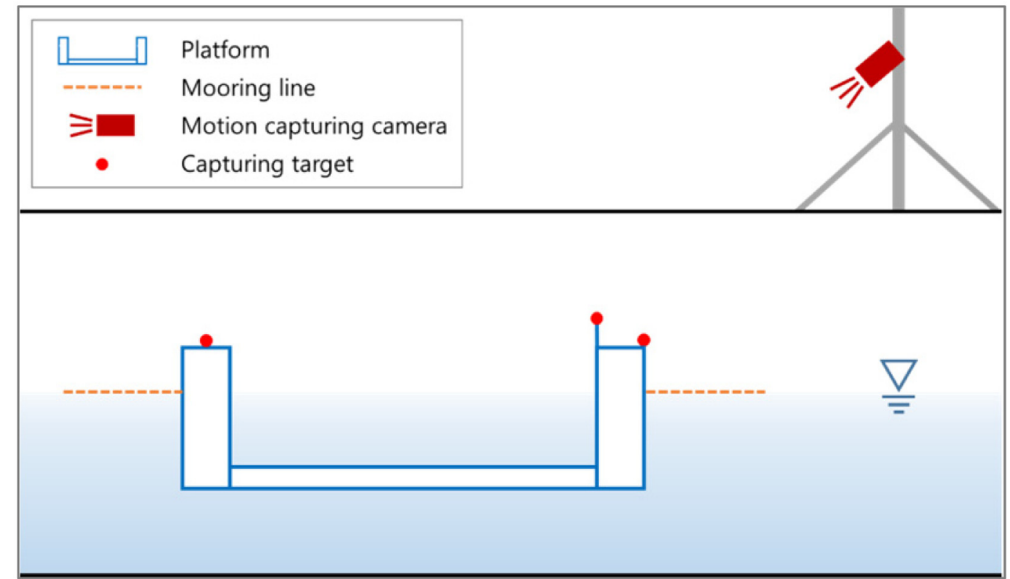

(a) Elevation view of schematic diagram

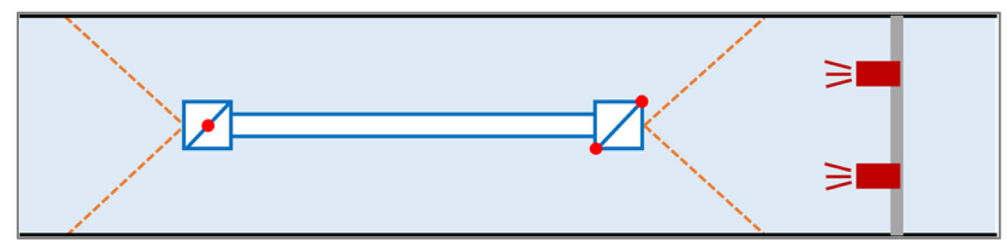

(b) Plan view of schematic diagram

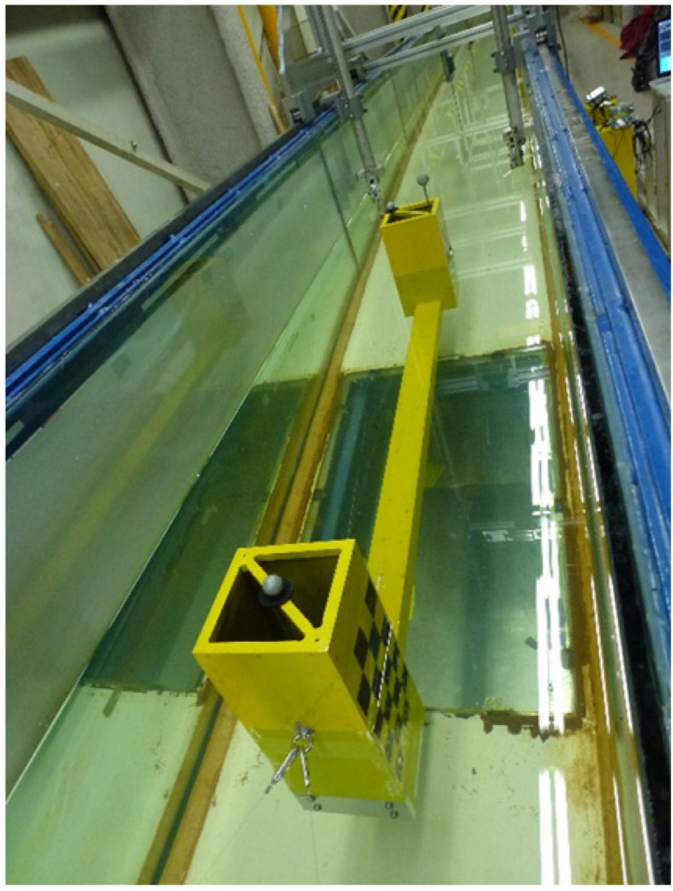

(c) Installed platform model in the wave flume

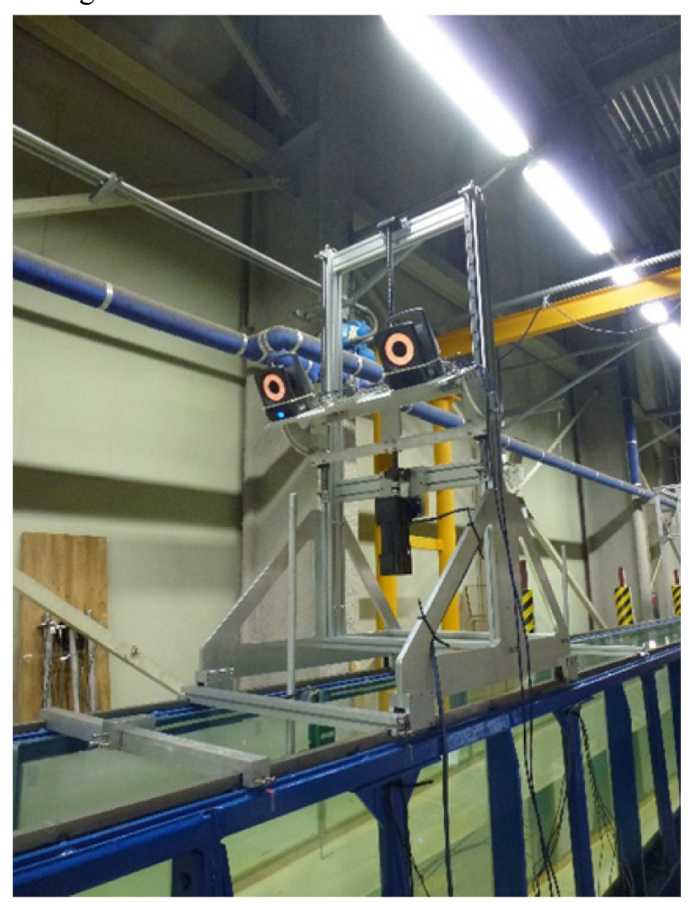

(d) Installed motion capture system with two T40-Cameras

Fig. 8 Expertimental Setups 
T40-Camera는 최대 4 Mega pixel, 최대 2,000FPS(Frame per second)의 제원을 갖춘 장비로, 타겟으로부터 반사된 빛을 센싱 하여 타겟의 변위를 계측할 수 있으며, 복수의 타겟 및 복수의 카메라를 활용하여 타겟의 6자유도 운동을 계측할 수 있다. Fig. 8 에는 조파수조 내에 설치된 모형 및 계측장비에 대한 모식도 와 실제로 설치된 모형 및 장비의 사진을 나타내었다.

모형 스케일로 $3 \mathrm{rad} / \mathrm{s} ~ 5.6 \mathrm{rad} / \mathrm{s}$ 의 파주파수 범위에서 $0.2 \mathrm{rad} / \mathrm{s}$ 간 격으로 총 14 개의 주파수 조건에 대해 $8 \mathrm{~cm}$ 파고의 규칙파를 생 성하여 모델에 입사시켰으며, 공진주파수 근처 조건에서는 $4 \mathrm{~cm}$ 파고 조건에 대해서도 RAO(Response amplitude operator)를 도출 하여 파고 불확실성을 제거하고자 하였다.

\section{5. 결 과}

\section{1 운동저감장치 민감도 해석}

\subsection{1 감쇠판의 배치형태}

수치해석을 통해 감쇠판의 다양한 배치형태에 대한 플랫폼의 부가질량, 파랑감쇠, 파랑기진력, 6자유도 운동 RAO를 계산하 였다. 본 논문에서는 운동저감 관점에서 중요한 상하동요 및 종 동요 수치해석 결과를 주로 나타내었다. Fig. 9에는 다양한 부착 형태 모델(Fig. 3)의 상하동요 및 종동요 운동 RAO를 나타내었 다. Num. model B의 종동요 공진응답이 가장 낮은 것으로 해석 되었으며, 상하동요의 경우에도 다른 모델에 비해 비교적 낮은

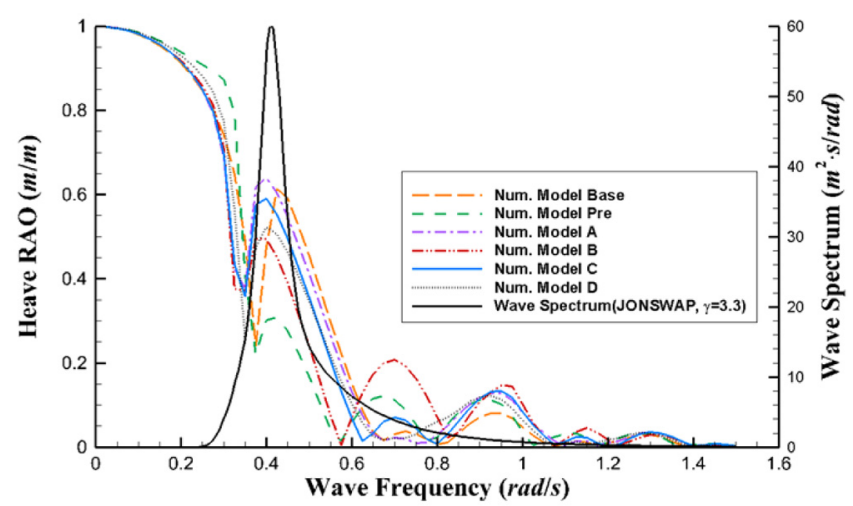

(a) Heave

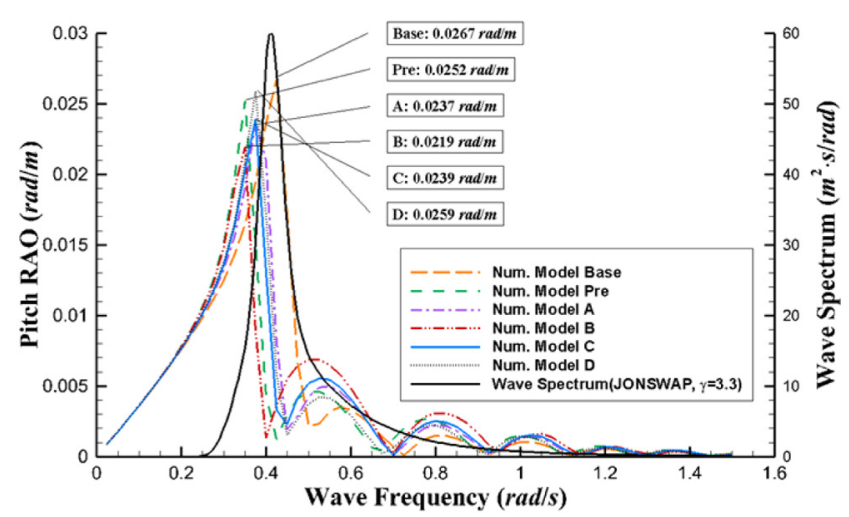

(b) Pitch

Fig. 9 Heave and pitch motion RAO for various configurations of the motion reduction device

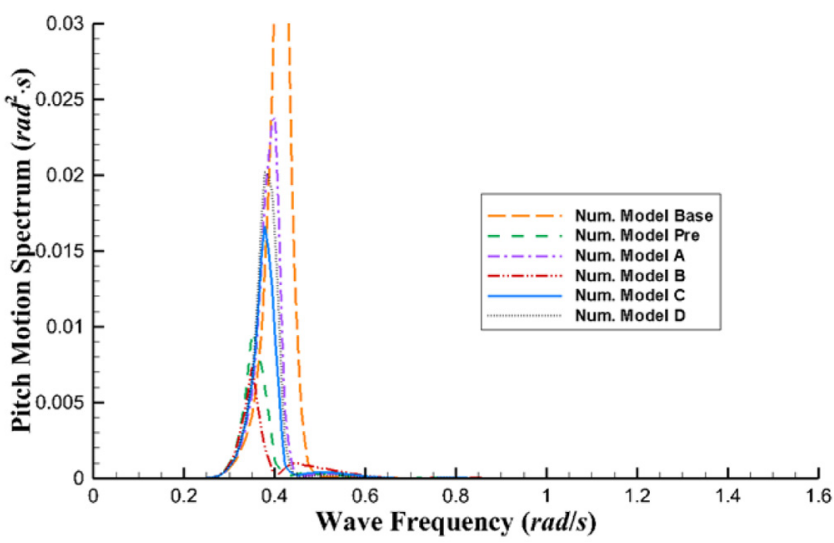

Fig. 10 Pitch motion response spectrums at the survival wave condition ( $\left.H_{s}=11.32 \mathrm{~m}, T_{p}=15.1 \mathrm{~s}\right)$ for various configurations of the motion reduction device

공진응답을 보여주었다. 그러나 공진응답이 저감된 반면 두번 째 정점에 해당하는 주파수 영역(상하동요 약 $0.6 \sim 0.8 \mathrm{rad} / \mathrm{s}$, 종동 요 약 $0.4 \sim 0.7 \mathrm{rad} / \mathrm{s}$ )에서는 응답이 증가하는 경향이 있었으며, 특 히 종동요의 경우 생존조건( 100 년 재현주기) 파랑의 정점주기 15.1 초 $(0.416 \mathrm{rad} / \mathrm{s})$ 가 공진응답 영역과 두번째 정점 영역에 겹쳐 있기 때문에 공진응답 평가만으로 최적안을 선정하는 것은 무 리가 있다. Fig. 10에는 다양한 부착형태 모델의 생존조건 파랑 스펙트럼에 대한 종동요 운동 응답스펙트럼을 나타내었다. 이 때, $H s$ 는 파랑스펙트럼의 유의파고, $T p$ 는 정점주기를 나타낸다. 모델간 결과를 비교해보면 감쇠판을 부착하지 않은 모델뿐만 아니라 다른 배치형태 모델보다도 Num. model B의 응답 스펙 트럼이 가장 낮았으며, 이는 공진주파수가 파랑 정점주파수로 부터 가장 멀리 떨어진 점과 파랑 정점주파수에서 종동요 응답 이 가장 낮았다는 점에서 기인한 것이다. 생존조건이 아닌 극한 조건(Extreme condition)이나 운용조건(operational condition)은 일 반적으로 생존조건에 비하여 유의파고가 낮고 정점주기가 짧아 해당 파랑조건을 고려하면 모델별로 다른 경향이 나타날 수 있 다. 그러나 생존조건의 유의파고 부근에서 가장 큰 운동이 나타 나게 되므로 본 연구에서는 이를 고려하여 다양한 부착형태 중 Num. Model B를 최적의 운동저감장치 부착형태로 선정하였다. 감쇠판은 플랫폼의 부가질량을 증가시켜 고유주기를 이동시 키고, 점성감쇠를 증가시켜 운동응답을 억제하기도 하지만 파 랑기진력도 증가시키기 때문에 상충효과를 잘 파악해야하며, 파랑기진력 증가효과를 최소화시키면서도 부가질량과 점성감쇠 를 많이 증가시킬 수 있는 방향으로 설계해야 한다. Fig. 11에는 다양한 부착형태에 따른 종동요 모드의 플랫폼 부가질량 및 파랑기진력 계산결과를 나타내었다. 생존조건 파랑 정점주파수 $(0.416 \mathrm{rad} / \mathrm{s})$ 부근에서 Num. model B의 부가질량이 가장 많이 증가하였으면서도 파랑기진력은 가장 작게 받는 것을 확인할 수 있다.

\subsection{2 감쇠판의 크기}

부착형태 민감도해석을 통해 도출한 최적 설계안 Num. Model $\mathrm{B}$ 에 대해 감쇠판의 크기를 변화시켜 그 성능을 검토하였다. Fig. 12에는 Num. model B의 다양한 크기 모델(Fig. 4)의 상하동 


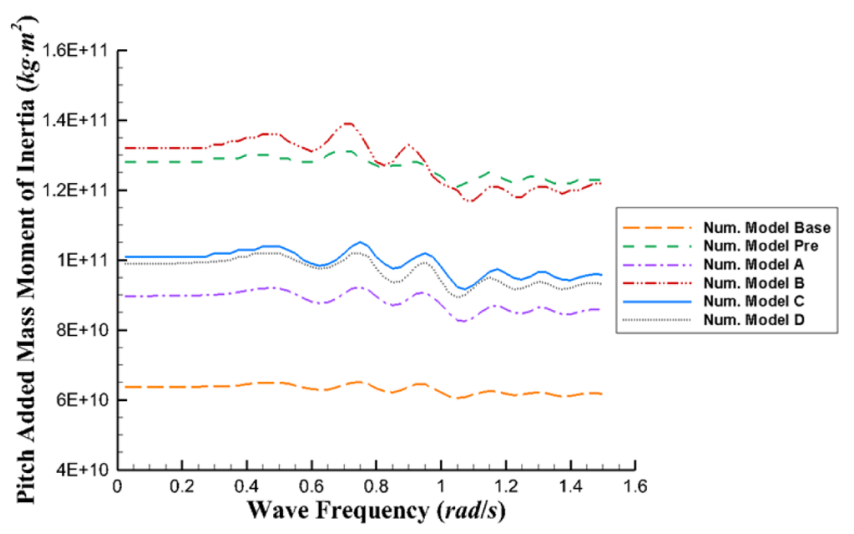

(a) Added mass

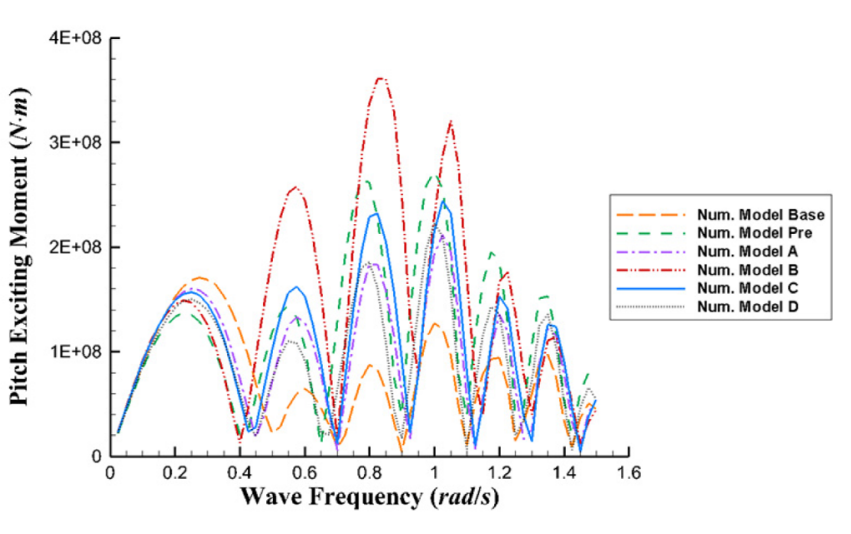

(b)Exciting moment

Fig. 11 Pitch added mass moment of inertia and exciting moment for various configurations of the motion reduction device

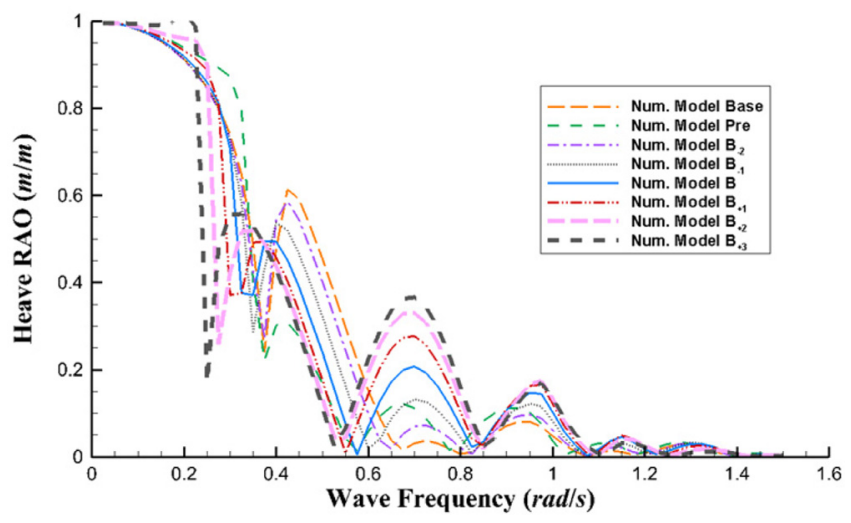

(a) Heave

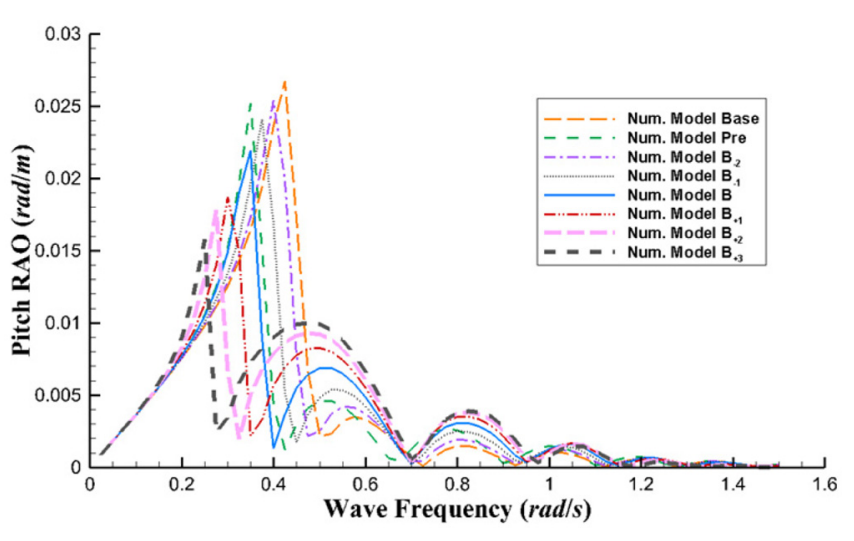

(b) Pitch

Fig. 12 Heave and pitch motion RAOs for various sizes of the motion reduction device (Num. model B)

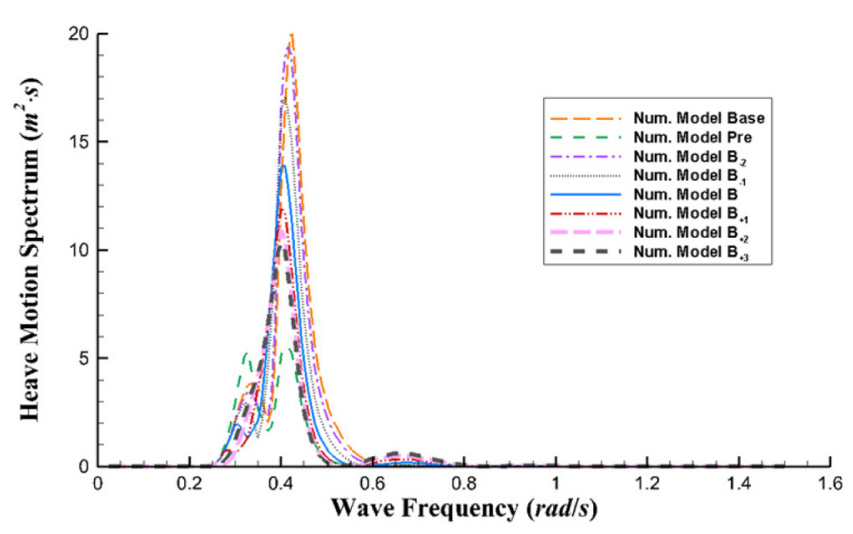

(a) Heave

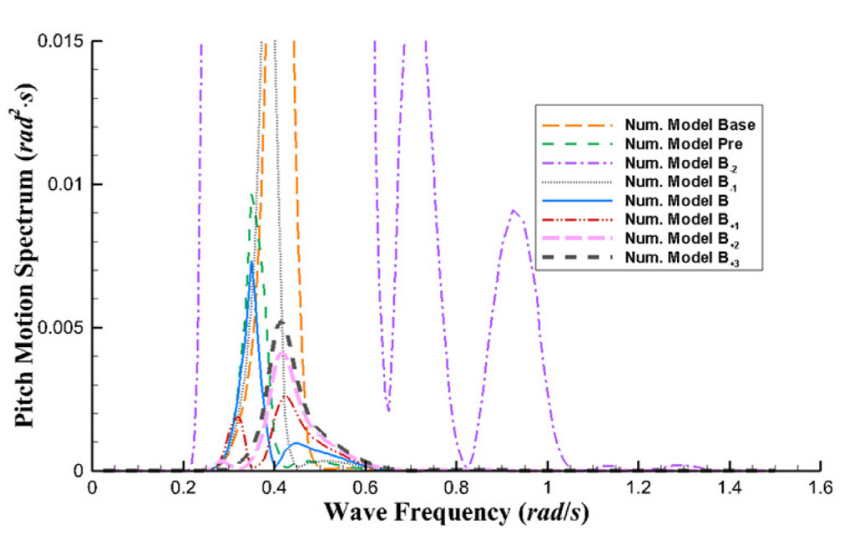

(b) Pitch

Fig. 13 Heave and pitch motion response spectrums at the survival wave condition $\left(H_{s}=11.32 \mathrm{~m}, T_{p}=15.1 \mathrm{~s}\right)$ for various sizes of the motion reduction device (Num. model B)

요 및 종동요 운동 $\mathrm{RAO}$ 를 나타내었다. 감쇠판의 크기가 증가할 수록 부가질량이 커지기 때문에 플랫폼의 공진주기는 상하동요 및 종동요 모두에서 점차 장주기 방향으로 이동하는 것을 확인 할 수 있었다. 그러나 상하동요의 경우 감쇠판의 크기가 증가할 수록 공진응답이 줄어들다가 다시 증가하는 경향이 있었고, 종 동요의 경우 점차 공진응답이 줄어들었으나 두번째 정점 영역 에서 반대의 경향을 보였다. Fig. 13 에는 Num. model B의 다양
한 크기 모델에 따른 상하동요 및 종동요 응답스펙트럼을 나타 내었다. 종동요 응답스펙트럼 결과에서 Num. model $\mathrm{B}_{+1}$ 이 가장 좋은 운동저감 성능을 보여주었다. 상하동요 관점에서는 해당 모델은 최적 설계안이 아니지만 운동저감장치의 주요목표인 종 동요 운동저감 효과 측면에서 가장 적합한 크기라고 볼 수 있 다. 따라서 본 연구에서는 컬럼 단면적 대비 5.1 배의 면적을 갖 는 감쇠판 설계안(Num. model $\left.\mathrm{B}_{+1}\right)$ 을 복합발전 플랫폼에 대한 


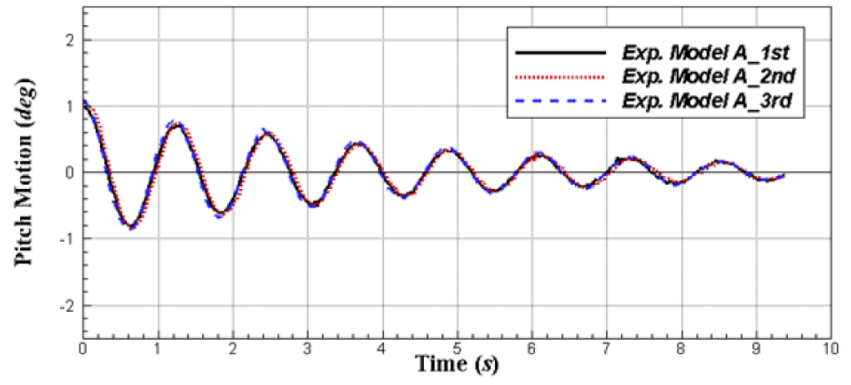

(a) Exp. model $\mathrm{A}$

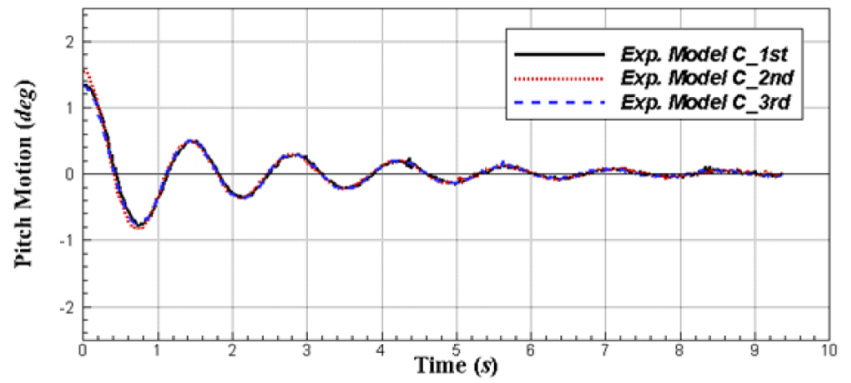

(c) Exp. model C

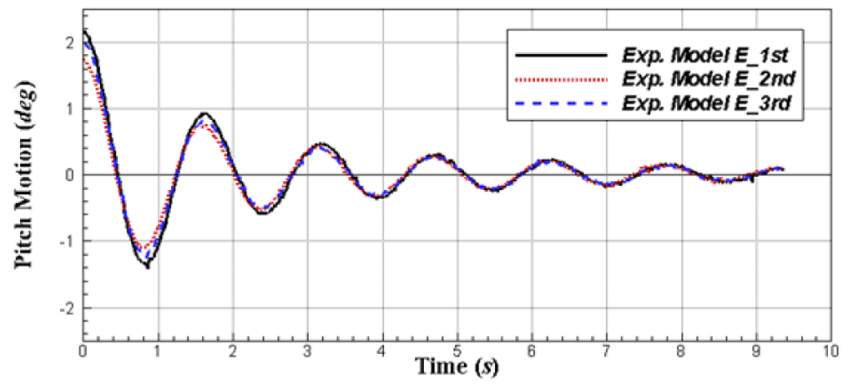

(e) Exp. model E

Fig. 14 Time series of pitch free decay tests (model scale)

운동저감장치 최적 설계안으로 선정하였다.

\section{2 운동저감장치 감쇠효과 평가 모형실험}

점성감쇠 영향을 고려할 수 있는 모형실험을 통해 운동저감장 치 설계모델에 대한 성능을 정성적으로 평가하였다. Fig. 14에는 자유감쇠실험을 통해 계측한 종동요 자유감쇠 운동 시계열을 각 모델 별(Fig. 6)로 나타내었다. 약 1 2 범위의 초기 종동요 변위 를 가한 뒤 시간에 따라 감쇠되는 플랫폼 종동요 변위를 $60 \mathrm{~Hz}$ 의 샘플링 주파수로 취득하였으며, 각 모델 별로 3 회씩 반복 실험하 였다. Table 6에는 각 모델 별로 반복 수행된 자유감쇠실험에서 평균을 통해 산출한 고유주기와 감쇠계수를 나타내었다. 이때 감 쇠계수는 임계감쇠(Critical damping)에 대한 백분율로 표시되어 있다. 각 시계열에 대해서는 각각 세번째까지의 양의 극값 (Positive peak) 및 음의 극값(Negative peak)에 대해 대수감쇠법 (Logarithmic decrement method)을 통해 계산된 감쇠계수를 모두 평균하여 임계감수에 대한 백분율을 산출하였다. 감쇠판이 부착 되지 않은 Exp. model A와 다른 모델들을 비교해보면, 공진주기 가 1.21 초에서 약 $0.2 \sim 0.3$ 초 정도 증가하였는데, 이는 감쇠판에 의해 증가된 종동요 부가질량에 일부 기인한 것으로 판단된다.

Fig. 15 에는 규칙파 중 종동요 운동 $\mathrm{RAO}$ 계측 결과를 각 모 델에 대해 나타내었다. Exp. model A를 제외하고는 Exp. model

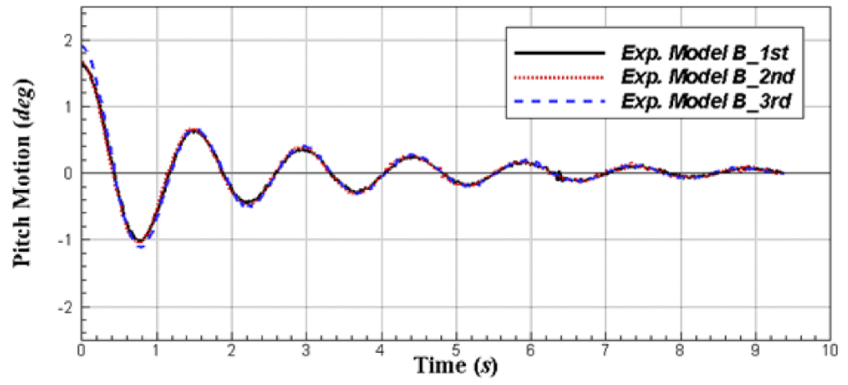

(b) Exp. model B

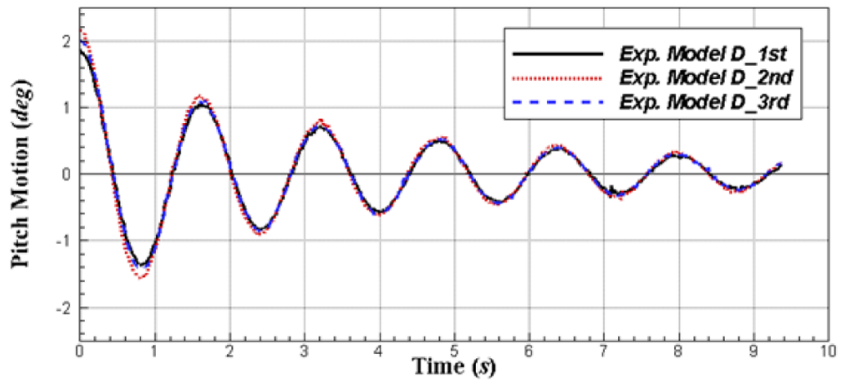

(d) Exp. model D

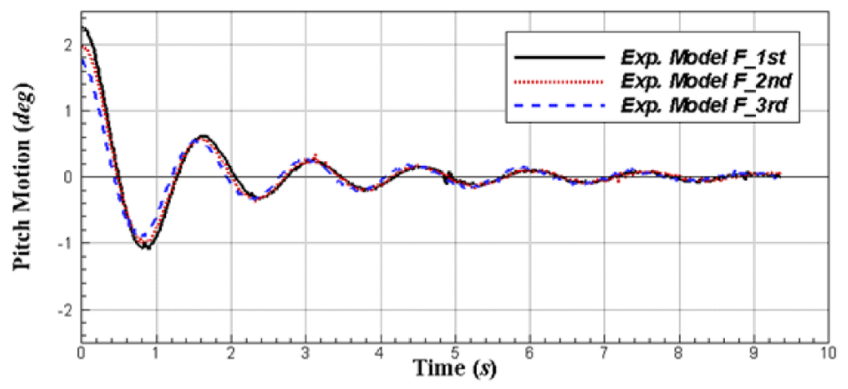

(f) Exp. model F

$\mathrm{B} F$ 의 경우, 자유감쇠실험에서 도출한 고유주기와 종동요 운동 $\mathrm{RAO}$ 커브의 공진점이 서로 일치하지 않는 것처럼 보이는데, 이 는 해당 모델들의 상하동요 공진점(약 $3.2 \mathrm{rad} / \mathrm{s})$ 에서 상하동요 와의 연성이 발생하여 해당 주파수 부근에서 공진이 발생한 것 이며, 실제 자유감쇠실험에서 도출한 고유주파수 부근(약 4.3 $\mathrm{rad} / \mathrm{s}$ 부근)에서는 점성감쇠에 의해 종동요 응답이 저감되었기 때문으로 판단된다. Exp. model A에 비해 감쇠판이 부착된 모델 들은 종동요 응답이 전반적으로 저감되었는데, 이는 각 모델 별 로 감쇠판이 점성감쇠를 증가시키는 역할을 하였기 때문이다. 박스형 감쇠구조가 부착된 Exp. model $\mathrm{D}$ 의 경우, 종동요 감쇠 (Table 6)도 높지 않을 뿐만아니라 박스형 감쇠구조가 파랑 기 진모멘트도 크게 받기 때문에 공진 응답이 상대적으로 다소 높 게 형성된 것으로 판단된다(Fig. 15). 또한, Exp. model B 및 C에 비해 Exp. Model E 및 F, 즉, 이중 감쇠판 형태의 모델의 감쇠가 가장 크지만(Table 6), 공진 응답은 예상만큼 낮지 않은 것으로 확인되었는데(Fig. 15), 이 또한 이중 감쇠판이 단일 감쇠판에 비해 파랑 기진모멘트를 더 많이 받기 때문인 것으로 판단된다. 그럼에도 불구하고 Exp. model B와 $\mathrm{C}$ 를 비교하거나, Exp. model $\mathrm{E}$ 와 $\mathrm{F}$ 를 종합적으로 비교해보면, 감쇠판의 공극에 의해 감쇠가 증가되었을 뿐만 아니라(Table 6), 플랫폼 공진응답도 공극에 의 해 감소된 것을 확인할 수 있다(Fig. 15). 이는 공극으로부터 점 
Conceptual Design of Motion Reduction Device for Floating Wave-Offshore Wind Hybrid Power Generation Platform 19

Table 6 Pitch natural periods and damping coefficients measured from free decay tests for each models (model scale)

\begin{tabular}{ccc}
\hline \hline Items & $\begin{array}{c}\text { Natural period } \\
{[\mathrm{s}]}\end{array}$ & $\begin{array}{c}\text { Pitch damping coefficient } \\
{[\%]}\end{array}$ \\
\hline Exp. model A & 1.21 & 4.13 \\
Exp. model B & 1.45 & 10.75 \\
Exp. model C & 1.39 & 10.93 \\
Exp. model D & 1.57 & 7.42 \\
Exp. model E & 1.54 & 11.05 \\
Exp. model F & 1.44 & 14.08 \\
\hline
\end{tabular}

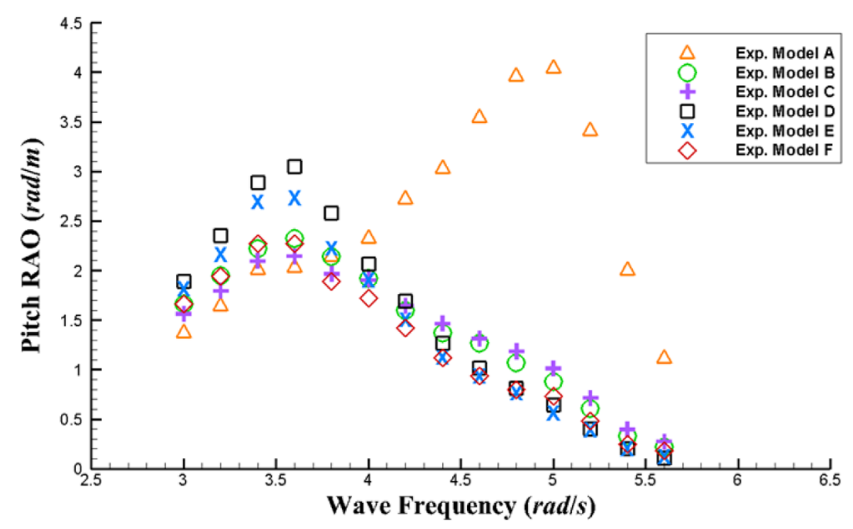

Fig. 15 Pitch RAO measured by the 2D wave flume experiments (model scale)

성감쇠에 의한 운동저감효과가 더 증대된 것을 나타내며, 공극 으로부터 와류 발생이 증가하였기 때문인 것으로 예측된다.

\section{6. 결 론}

본 연구에서는 파력-해상풍력 복합발전 대형 부유식 반잠수 식 구조물의 운동을 저감시키기 위한 감쇠판의 개념설계를 수 행하였다. 경계요소법 수치해석을 이용하여 다양한 부착형태 및 크기에 대한 민감도해석을 수행하였으며, 100 년 재현주기의 생존조건 파랑 스펙트럼에 대해 Num. model B+1 모델(Fig. 4 (d))이 복합발전 플랫폼의 종동요 운동을 효과적으로 억제시키 는 것을 확인하였다.

점성감쇠 효과를 평가하기 위하여, 수치해석을 통해 선정된 감 쇠판 설계 모델 및 점성감쇠 효과를 증진시키도록 고안된 다수의 설계 모델을 2차원 조파수조 모형실험에 적합하도록 이상화하여 자유감쇠 운동 및 규칙파 중 종동요 운동을 평가하였다. 자유감 쇠실험을 통해 각 감쇠판 모델의 감쇠를 정량적으로 평가하였으 며, 규칙파 중 종동요 운동 $\mathrm{RAO}$ 를 비교함으로써 Exp. model $\mathrm{C}$ 모델(Fig. 6(c))의 공진응답이 최대로 억제된 것을 확인하였다.

본 연구를 통해 Num. model B+1의 면적으로 외부폰툰-컬럼외부폰툰 연결부 내측 하단에 부착되면서 Exp. model C와 같이 공극을 갖는 감쇠판이 복합발전 플랫폼의 종동요 운동을 효과 적으로 저감시킬 것으로 기대할 수 있으며, 향후 전체 플랫폼에 대한 3차원 수조 모형실험을 통해 설계 모델에 대한 정량적인
성능평가가 가능할 것으로 사료된다.

한편 점성감쇠를 평가하기 위해 수행한 자유감쇠 실험에서 와류 발생에 의한 점성감쇠를 보다 정확하게 평가할 수 있도록 비선형 감쇠에 대한 해석이 향후연구에서 보완되어야 할 것으 로 판단된다.

\section{후 기}

본 연구는 해양수산부의 해양청정에너지기술개발사업 ' $10 \mathrm{MW}$ 급 부유식 파력-해상풍력 연계형 발전시스템 설계기술 개발(PMS3170)' 및 ‘방파제 연계형 파력발전 융복합 기술개발(PMS3780)'의 지원으 로 수행되었으며, 연구비 지원에 감사드립니다.

\section{References}

Butterfield, S., Musial, W., Jonkman, J., Sclavounos, P., Wayman, L., 2005. Engineering Challenges for Floating Offshore Wind Turbines. Proceedings of Copenhagen Offshore Wind 2005 Conference and Expedition, Copenhagen Denmark.

Busso, C., 2006. Minimum Floating Offshore Platform with Water Entrapment Plate and Method of Installation. United States Patent, US7086809 B2.

Cermelli, C.A., Roddier, D.G., Busso, C.C., 2004. MINIFLOAT: A Novel Concept of Minimal Floating Platform for Marginal Field Development. Proceedings of $14^{\text {th }}$ International Offshore ad Polar Engineering Conference, Toulon France, 538-545.

Cermelli, C.A., Roddier, D.G., 2005. Experimental and Numerical Investigation of the Stabilizing Effects of a Water-Entrapment Plate on a Deepwater Minimal Floating Platform. Proceedings of $24^{\text {th }}$ International Conference on Ocean, Offshore and Artic Engineering, Halkidiki Greece, 517-525.

Cermelli, C.A., Roddier, D.G., Aubault, A., 2009. WINDFLOAT: A Floating Foundation for Offshore Wind Turbine - Part II: Hydrodynamic Analysis. Proceedings of $28^{\text {th }}$ International Conference on Ocean, Offshore and Artic Engineering, Honolulu USA, 135-143.

Det Norske Veritas(DNV), 2010. Environmental Conditions and Environmental Loads. [Online] (Updated October 2010) Available at: $<$ https://exchange.dnv.com/publishing/downloadPDF. asp?url=http://exchange.dnv.com/publishing/codes/docs/201404/RP-C205.pdf> [Accessed March 2014].

Det Norske Veritas(DNV), 2013. WADAM User Manual - Wave Analysis by Diffraction and Morison Theory. [Online] Available at: <https://projects.dnvgl.com/sesam/manuals/Wadam_UM.pdf $>$ [Accessed March 2014].

Enferad, E., Nazarpour, D., 2013. Ocean's Renewable Power and Review of Technologies: Case Study Waves, New Developments in Renewable Energy. [Online] (Updated 2013) Available at: $<$ http://www.intechopen.com/books/new-developments-in-ren ewable-energy/ocean-s-renewable-power-and-review-of-techn 
ologies-case-study-waves $>$ [Accessed June 2015].

Iglesias, A.S., Rojas, L.P., Rodriguez, R.Z., 2004. Simulation of Anti-Roll Tanks and Sloshing Type Problems with Smoothed Particle Hydrodynamics. Ocean Engineering, 31(8), 1169-1192. Javier, M., Matt, C., Krish, P.T., 2015. Hydrodynamic Performance of Heave Plates on Floating Offshore Wind Turbine Platforms. Proceedings of $25^{\text {th }}$ International Offshore and Polar Engineering Conference, Kona USA, 408-414.

Katayama, T., Yoshioka, Y., Kakinoki, T., Ikeda, Y., 2010. Some Topics for Estimatino of Bilge-Keel Component of Roll Damping. Proceedings of $11^{\text {th }}$ international Ship Stability Workshop, Wageningen Netherlands, 225-230.

Kim, K.-H., Lee, K., Sohn, J.M., Park, S., Choi, J.-S., Hong, K., 2015. Conceptual Design of 10MW Class Floating WaveOffshore Wind Hybrid Power Generation System. Proceedings of $25^{\text {th }}$ International Ocean and Polar Engineering Conference, Kona USA, 737-743.

Koh, H-J, Cho, I-H, 2016. Heave Motion Response of a Circular Cylinder with the Dual Damping Plates. Ocean Engineering, 125, 95-102.

Lee, C.-H., 1995. WAMIT Theory Manual. [Online] (Updated October 1995) Available at: <http://www.wamit.com/Publications/ tmanual.pdf $>$ [Accessed March 2014].

NRG Expert, 2011. Global Ocean Energy Report. 1st Edition, NRG Expert, London.

Palomar, A.J., 2013. Project Periodic report - Development of a Wind-Wave Power Open-Sea Platform Equipped for Hydrogen Generation with Support for Multiple Users of Energy. [Online] Available at: <http://cordis.europa.eu/docs/results/288145/ periodic1-h2ocean-propereport-m18-v5-9-publishable-summar y.pdf> [Accessed June 2015].
Park, S.-W., Kim, K.-H., Sohn, J.-M., Lee, K.-S., Shin, S.-H., Hong, K., 2014. Numerical Simulation on Hydrodynamic Motion Response for Floating Hybrid Power Generation System in Waves. Proceedings of Grand Renewable Energy 2014, Tokyo Japan.

Pauline, B., Adrien, E., 2015. CFD Simulations for the Design of Offshore Floating Wind Platforms Encompassing Heave Plates. Proceedings of $25^{\text {th }}$ International Offshore and Polar Engineering Conference, Kona USA, 375-384.

Perez, T., Goodwin, G.C., 2008. Constrained Predictive Control of Ship Fin Stabilizers to Prevent Dynamic Stall. Journal of Control Engineering Practice, 16, 482-494.

Rho, J.B., Choi, H.S., 2002. Heave and Pitch Motions of a Spar Platform with Damping Plate. Proceedings of $12^{\text {th }}$ International Offshore and Polar Engineering Conference, Kitakyushu Japan, 198-201.

Soulard, T., Babarit, A., Borgarino, B., 2013. Preliminary Assessment of a Semi-Submersible Floating Wind Turbine Combined with Pitching Wave Energy Converters. Proceedings of $10^{\text {th }}$ European Wave \& Tidal Energy Conference, Aalborg Denmark.

Subbulakshmi, A., Sundaravadivelu, R., 2015. Effect of Heave Plate on Hydrodynamic Response of Spar. Proceedings of 25th International Offshore and Polar Engineering Confernce, Kona USA, 1439-1445.

Tao, L., Cai, S., 2004. Heave motion suppression of a spar with a heave plate. Journal of Ocean Eng, 31, 669-692.

Yde, A., Larsen, T.J., Hansen, A.M., Fernandez, M., Bellew, S., 2015. Comparison of Simulations and Offshore Measurement Data of a Prototype of a Floating Combined Wind and Wave Energy Conversion System. Proceedings of $25^{\text {th }}$ International Ocean and Polar Engineering Conference, Kona USA, 721-729. 